2019-11-20

\title{
Biomonitoring acidification using marine gastropods
}

Marshall, DJ

http://hdl.handle.net/10026.1/15006

10.1016/j.scitotenv.2019.07.041

Science of the Total Environment

Elsevier

All content in PEARL is protected by copyright law. Author manuscripts are made available in accordance with publisher policies. Please cite only the published version using the details provided on the item record or document. In the absence of an open licence (e.g. Creative Commons), permissions for further reuse of content should be sought from the publisher or author. 
This is the author's accepted manuscript. The final published version of this work (the version of record) is published by Elsevier in Science of the Total Environment. The accepted manuscript was made available online on the 15 July 2019 at: https://doi.org/10.1016/i.scitotenv.2019.07.041 This work is made available online in accordance with the publisher's policies. Please refer to any applicable terms of use of the publisher.

\section{Biomonitoring acidification using marine gastropods}

David J. Marshall ${ }^{1 *}$, Ahmed Awad Abdelhady ${ }^{2}$, Dennis Ting Teck Wah ${ }^{1}$, Nurshahida Mustapha $^{1}$, Stefan H. Gödeke ${ }^{3}$, Liyanage Chandratilak De Silva ${ }^{4}$, Jason M. Hall-Spencer ${ }^{5,6}$

${ }^{1}$ Environmental and Life Sciences, Faculty of Science, Universiti Brunei Darussalam, Brunei Darussalam; ${ }^{2}$ Geology Department, Faculty of Science, Minia University, El-Minia 61519, Egypt; ${ }^{3}$ Geological Sciences, Faculty of Science, Universiti Brunei Darussalam; ${ }^{4}$ Faculty of Integrated Technologies, Universiti Brunei Darussalam; ${ }^{5}$ School of Biological and Marine Sciences, University of Plymouth, UK; ${ }^{6}$ Shimoda Marine Research Center, Tsukuba University, Japan.

*Corresponding author: David J. Marshall, Environmental and Life Sciences, Faculty of Science, Universiti Brunei Darussalam, Jalan Tungku Link, BE1410, Gadong, Brunei Darussalam. Email: david.marshall@ubd.edu.bn; Tel.: +673 8974143 


\section{Abstract}

Ocean acidification is mainly being monitored using data loggers which currently offer limited coverage of marine ecosystems. Here, we trial the use of gastropod shells to monitor acidification on rocky shores. Animals living in areas with highly variable $\mathrm{pH}(8.6-5.9)$ were compared with those from sites with more stable $\mathrm{pH}(8.6$ - 7.9). Differences in site $\mathrm{pH}$ were reflected in size, shape and erosion patterns in Nerita chamaeleon and Planaxis sulcatus. Shells from acidified sites were shorter, more globular and more eroded, with both of these species proving to be similarly good biomonitors. After an assessment of baseline weathering, shell erosion can be used to indicate the level of exposure of organisms to corrosive water, providing a tool for biomonitoring acidification in heterogeneous intertidal systems. A shell erosion ranking system was found to unequivocally discriminate between acidified and reference sites. Being spatially-extensive, this approach can identify coastal areas of greater or lesser acidification. Cost-effective and simple shell erosion ranking is amenable to citizen science projects and could serve as an early-warning-signal for natural or anthropogenic acidification of coastal waters.

Keywords: ocean acidification; bioindicators; acid sulphate soils; calcification; snails; tropical

\section{Introduction}

Monitoring changes in the corrosiveness of seawater is crucial to managing and predicting the impact of ocean acidification. The past two decades have seen an increase in the global deployment of fixed buoys equipped with instruments and data-loggers. These monitoring stations capture long-term changes in seawater chemistry but are costly to implement and maintain, and provide data from discrete points. Biomonitoring may provide a complementary method for assessing acidification in coastal waters. Shelled gastropods can be useful biomonitoring organisms (Gibbs et al., 1987; Phillips and Rainbow, 1993; Zhou et al., 2008; Nuñez et al., 2012, Márquez et al., 2015; Proum et al., 2016; Begliomini et al., 2017) and so oceanographers have begun to use pteropod shell dissolution to assess the effects of 
approach using benthic gastropods to assess acidification impacts in shallow-water coastal habitats.

Studies of benthic gastropods have contributed significantly to our understanding of the ecological consequences of ocean acidification (Lardies et al., 2014; Garilli et al., 2015). Much of this work has focussed on the energetic costs of calcification in acidified water (Chen et al., 2015; Harvey et al., 2016, 2018; Connell et al., 2017; Duquette et al., 2017; Doubleday et al., 2017; Harvey et al., 2018). Gastropod shell mineralogy, dissolution and gross shell deformities are well documented, especially for $\mathrm{CO}_{2}$ seep systems (Hall-Spencer et al., 2008; Chen et al., 2015; Duquette et al., 2017), yet no studies have assessed how well these features record episodes when seawater becomes corrosive to shells and skeletons.

Fluctuations in carbonate chemistry in near-shore marine environments arise from multiple natural and anthropogenic processes, with a major influence from the land via rivers, estuaries and sediments (Zhai et al., 2015). Carbonate undersaturation in coastal waters can be caused by flooding and reduced salinities, or eutrophication (Cai et al., 2011 a, b; Duarte et al., 2013; Zhai et al., 2015). Coastal acidification also develops through geochemical discharge from acidic soils (Powell and Martens, 2005; Grealish and Fitzpatrick, 2013). In Brunei (Borneo, South East Asia), a combination of eutrophication, peat swamp leachate, acidic pollutants and acid sulphate soils cause coastal acidification (Marshall et al., 2008; Grealish and Fitzpatrick, 2013; Proum et al., 2016, 2018), reducing biodiversity and affecting ecosystem functions (Marshall et al., 2016, 2018). A steep pH gradient in the Brunei estuarine system has been used to assess marine organism and community responses to acidification (Bolhuis et al., 2014; Hossain and Marshall, 2014; Majewska et al., 2017; Proum et al., 2017).

Gastropod snails with heavily corroded shells inhabit the rocky intertidal zone on the open coast of Brunei, away from influence of the estuarine system. Here we investigated the effect of acidic water discharge on rocky shore seawater $\mathrm{pH}$. We then tested whether gastropods can be used to inform about corrosive water conditions on rocky shores, by comparing between responses to acidified and normal seawater exposure using two species. An overarching objective was to appraise methods using shells of benthic gastropods to monitor corrosive seawater events.

\section{Materials and Methods}




\subsection{Geology and study sites}

The South China Sea coast of Brunei Darussalam has sandstone ridges separated by clay sediments containing pyrite $\left(\mathrm{FeS}_{2}\right)$ and pyritic minerals (Morley et al., 2003) which react when exposed to oxygen according to the equation:

$2 \mathrm{FeS}_{2}+7 \mathrm{O}_{2}+2 \mathrm{H}_{2} \mathrm{O}=>2 \mathrm{Fe}^{2+}+4 \mathrm{SO}_{4}{ }^{2-}+4 \mathrm{H}^{+}$

This lowers the $\mathrm{pH}$ of water that flows from the land into the South China Sea (Grealish and Fitzpatrick, 2013) (Fig. 1). Water enters the coastal ecosystem via tributaries and watercourses, or through discharges of submarine or subterranean groundwater, which can be below $\mathrm{pH} 4$ (Azhar et al., 2019; Waska et al., 2019; Fig. 1). Topography, tides, currents and waves influence the area of seawater affected by groundwater discharge (Urish and McKenna, 2004; Waska et al., 2019).

Eight sites were selected based on the occurrence of Nerita chamaeleon Linnaeus, 1758 (Neritoidea) and Planaxis sulcatus (Born, 1778) (Cerithioidea) and on the presence of intertidal acidic water discharge (Fig. 1). Three sites were strongly influenced by acidified water (E1, E2 and E3; A1) whereas the reference sites were not (JPMC, PJER, PUN, TP, UB). PUN and E13 were natural rocky shores, whereas the others were artificial seawalls (Fig. 1, A1). At low tide E1-3 had acidified water running over mixed sand and boulders exposing both species of gastropod to acidified water although when the tide was in, seawater $\mathrm{pH}$ and salinity were normal (Grealish and Fitzpatrick, 2013; A1). Sites were separated by km scale distances, except E1-3 which were approximately $>100 \mathrm{~m}$ apart. Physicochemical characteristics, such as temperature and oxygen content, were similar across the sites.

\subsection{Sampling}

A total of 124 water samples (40 ml, between 9-32 per site) were collected from snail habitat in the intertidal zone on thirteen trips in April-July 2018. Samples were taken to measure pH and salinity ranges during low-tide, including from small pools on the high shore, and from the open sea on the low shore. Sometimes small water-bodies were sampled with a syringe. On return to the laboratory, water parameters were measured at $24^{\circ} \mathrm{C}$, the laboratory and nighttime field temperature. Salinity was measured using a Hach multi-meter (model HQ40d) with an Intellical probe (Hach Lange GmbH Headquarter, Düsseldorf, Germany). pH was measured using a Mettler Toledo $\mathrm{pH}$ transmitter 2100e and probe (Mettler-Toledo GmbH, Giessen, Germany) calibrated with $\mathrm{pH} 4.00$ and 7.00 CertiPUR Merk buffers traceable to SRM from 
NIST. Repeated measures of the same sample yielded a reading precision of \pm 0.012 (s. d. , $n=10$ ).

Nerita chamaeleon and P. sulcatus are common on rocky-shores in this region of Asia. Individuals of both species occupy hard-substrata, intertidal pools, and sometimes soft sediments between boulders, across a broad mid-tidal zone (approximately 0.5-1.5 m Chart Datum). Abundance in both cases can exceed 50 snails per $\mathrm{m}^{2}$. The species differ greatly in shell shape with the shell of $N$. chamaeleon expanded diametrical and compressed axially and that of P. sulcatus expanded axially (Figs. 2 and 3). Similar-sized living adults (20-30 mm for both species) were collected and analysed between Dec 2016 and Jul 2018. Snails of $N$. chamaeleon $(\mathrm{n}=132)$ and $P$. sulcatus $(\mathrm{n}=147)$ were stored in $70 \%$ ethanol within an hour of collection. Shell size, shape and surface erosion were then measured or ranked.

We compared between the reference and acidified sites using attributes of either species. The same attribute was not always determined for both species, with shell shape often dictating the approach followed. For example, it was not feasible to assess shell shape variation using conventional geometric morphometric landmarks in the case of the globular-shaped Nerita chamaeleon, which has severely compressed spire whorls.

\subsection{Size, mass and shell shape}

Shell height, aperture length, dry shell mass and dry soft tissue mass were measured for $N$. chamaeleon from E1 (acidified) and PUN (reference) (Fig. 1). After photographing apertural and abapertual shell surfaces (Canon EOS 5D, Mark II, $100 \mathrm{~mm}$ macrolens), length was measured using Olympus CellSens software (A2). Shells were then cracked open and separated from soft tissues. Following oven-drying at $70^{\circ} \mathrm{C}$ for three days, the tissue was weighed with a balance accurate to $0.001 \mathrm{~g}$.

Shell length and mass data were scaled to a common aperture length (Marshall et al., 2008, A2). As shell morphology varies allometrically, measurements were converted to natural logarithms before fitting ordinary least squares regressions to plots (Sigmaplot ver. 14, Systat Software, Inc., New York, US). The effect of site (PUN and E1) was assessed using Generalized Linear Models for normal distribution with a log-link function (Statistica ver. 12, StatSoft, New York, US).

Shell shape analyses of $P$. sulcatus used samples from E2 (acidified), TP and UB (reference), and followed methods described by Abdelhady et al. (2018). Each individual was photographed 
(> 20 per site) and twenty landmarks of the shell were digitized using the TPSDig Package (http://life.bio.sunysb.edu/morph/, Rohlf, 1996; A3). The error associated with capturing 2D image from 3D object was minimized (see Abdelhady, 2016). Generalized Procrustes Analysis was applied to these data using the method of Rohlf and Slice (1990) to ensure that distances among homologous landmarks were minimized such that the resulting data best represented the shape. Procrustes residual data were projected to Detrended Corresponding Analysis (DCA) to arrange the shell shape data on coordinates (see Abdelhady and Fürsich, 2014, 2015). Analysis of Similarities (ANOSIM) was applied to test the null hypothesis that similarities between sites are smaller or equal to similarities within sites. Finally, Thin Plate Spline was used to assess changes in shell shape between specimens (see Zelditch et al., 2012). Statistical analyses were carried out using PAST version 2.17c (Hammer et al., 2001, 2006).

\subsection{Shell surface erosion}

Shell erosion areas, representing lifetime exposures, were assessed quantitatively or using a ranking system. Two methods were used to quantify erosion areas from photographs of the abapertural side of $N$. chamaeleon collected from PUN (reference) and E1 (acidified) in Dec 2016. Our first method involved manually demarcating and calculating planar surface area (2D) of erosion down to the light grey, fine-textured layer using an Olympus CellSens drawing tool (A2). The eroded area was then expressed as a proportion of the total surface area of the shell. Generalized Linear Models for a normal distribution and log-link function (Statistica ver. 12, StatSoft, New York, US) were used to assess the effect of acidification. For each site, we counted the number of individuals showing no erosion as well as those showing eroded surfaces of $>10 \%$ of the total area.

Inaccuracies in delineation of areas arose when erosion occurred in the fine grooves of shells (A2), so we applied a second method to $N$. chamaeleon shells based on digital pixel analysis. We developed software that used k-mean clustering, which assigns observations to clusters using Mahalanobis distance measures. We grouped our data into background (white colour), eroded shell surfaces (light colour) and unaffected shell surfaces (dark colour). The digital method was then compared with our manual assessment of eroded areas using a linear regression (Statistica ver. 12).

Shell Erosion Ranks (SERs) were determined for both species (Figs 2 and 3) using different criteria for pragmatic reasons (shell shape). For $N$. chamaeleon, erosion ranks were based on apical images of the shell. The image was divided into seven sectors, each representing a 
different shell age (Fig. 2). A $0-7$ rank, based on the highest numbered sector with $>50 \%$ surface erosion was determined for two types of erosion. Type I was deep erosion to homogenous non-pigmented fine-textured shell and Type II was superficial erosion of the outer 'prismatic' layer containing slight ridges and pigmented shell. Our analyses were based on either the rank for Type I (0-7) or that for both types summed to give a final rank between 0 14 (Fig. 2). A shell that was completely covered by periostracum was scored zero. In $P$. sulcatus, shell erosion was ranked using abapertural and apertural photographs (see Fig. 3 for details of the abapertural ranking method). Data were statistically analysed using Generalized Linear Models with a probit function for an ordinal multinomial distribution (Statistica ver. 12). Median scores and frequency distributions of ranks were plotted.

\section{Results}

\subsection{Habitat $\mathrm{pH}$ and salinity}

Upper $\mathrm{pH}$ values were similar for all stations (mean $\max \mathrm{pH} \pm$ s.d. $=8.50 \pm 0.08, \mathrm{n}=6$ ). $\mathrm{pH}$ ranges were $8.56-7.90(n=63)$ for the reference sites and $8.60-5.93(n=61)$ for the acidified sites (Fig. 4). Salinities were 33.2-20.2 for the reference sites and $32.8-0.2$ for the acidified sites. In a nearby estuary, lower $\mathrm{pH}$ and salinity generated through acidic groundwater discharge causes calcite $(\mathrm{Ca})$ and aragonite (Ar) undersaturation, and so snails at our acidified sites (E1-3) are likely to experience corrosive water exposure (Fig. 4, bottom panel).

\subsection{Size, mass and shape}

Shells of $N$. chamaeleon from the acidified site were shorter than those at the reference site $(\mathrm{A} 4$; Wald stat $=12.88, \mathrm{p}=0.0003)$. Shell and dry tissue mass did not differ significantly between the sites (Wald stat $=3.42, \mathrm{p}=0.064$ and Wald stat $=0.15, \mathrm{p}=0.694$, respectively; A4). In the shape analysis of $P$. sulcatus, cumulative plots of the average sizes confirmed the suitability of using $\sim 20$ specimens with little change in this average when more specimens were added. Reference-site $P$. sulcatus had similar shell shapes whereas the acidified-site specimens had a larger width/height ratio (ANOSIM; $p<0.01$; Fig. 5). DCA confirmed that acidified-site snails had shorter shells with larger apertures. Shell shapes were similar for the reference populations, which differed from the acidified population (DC1 versus DC2, Fig. 5). Apertures were rounder (DC1 versus aperture shape; $r=0.44$; Fig. 5) and shells were more globular in acidified conditions (DC2 versus shell height; $r=-0.48$; Fig. 5).

\subsection{Shell surface erosion}


Shells from acidified sites were more eroded than those at reference sites (Fig. 6). Differences were found for manually-calculated absolute areas and areas relative to the total shell surface (Fig. 6 A, B, C; p < 0.001). The average amount of eroded surface of acidified site snails was $>40 \%$, compared to $<10 \%$ in reference site snails (Fig. 6). Only one acidified site snail had no dissolution (Fig. 6 D).

In our digital technique, surface erosion areas were coloured red $v s$ blue for unaffected areas (Fig. 7). Results from our automated approach and our manual calculations were closely correlated $(r=0.91 ; p<0.05 ;$ Fig. 7$)$, though the manual method underestimated eroded areas in shell grooves. Due to its simplicity, the automated technique could be used for large sample analysis although visual checks are needed, such as when the colour of eroded shell areas is similar to that of uneroded areas.

Shell Erosion Ranks (SERs) indicated much more extensive erosion at the acidified sites (Figs 8 and 9). Reference site $N$. chamaeleon had a median SER of 5 whereas snails from acidified sites had a rank of 10. There were however differences within the groups of reference or acidified sites; PUN shells had greater erosion than JPMC and PJER, and E1 and E2 had more erosion than E3 (Fig. 8 A; Table 1). SER frequencies were highly discriminatory in that ranks of 5 and 6 (Type I), representing the most severe erosion, were only found at the acidified sites (Fig. 8 B). These patterns were repeated in P. sulcatus with a median erosion rank of $\sim 6.5$ at the reference sites compared with $\sim 9$ for the acidified sites (Fig. 9; Table 1). Whereas most of the snails at the acidified sites had erosion ranks $>5$, the highest rank recorded at the reference sites was 4 and none of the snails at the acidified sites ranked 2 or less (Fig. 9 B). High frequencies of the unique highest (or higher) erosion ranks were found at the acidified sites; ranks 5 or 6 for $N$. chamaeleon collectively contributed more than 0.4 of all individuals and rank 5 for $P$. sulcatus contributed around 0.6 of these populations.

\section{Discussion}

Gastropod shells have been used to monitor spatial patterns of acidification in oceanic pelagic systems (Bednaršek et al., 2012a, 2012b, 2014) but not in coastal ecosystems. We found that acidification of a rocky intertidal system was reflected in the shell attributes of two gastropod species, with shell surface erosion patterns correlating with acidification.

Groundwater discharge affected open coast rocky shores of the region, with some rockpools as low as $\mathrm{pH} 5.9$, adding to previous observations of the effects of acidification on the ecology of an estuarine system in Brunei (Marshall et al. 2008, 2016; Bolhuis et al., 2014; Hossain et al., 
2014; Majewska et al., 2017; Proum et al., 2017, 2018). Land-to-sea acidification via submarine groundwater flux or water-course infiltration had little effect on $\mathrm{pH}$ at the reference sites compared to that of direct discharge at the acidified sites (Urish and McKenna, 2004). Rockpool pH and salinity fell to levels likely to produce carbonate undersaturation (Fig. 3; Kim et al., 2014; Proum et al., 2018).

Shell length, shape, and erosion varied greatly between the acidified and reference sites, whereas tissue and shell masses were similar (A4). Acidified water exposure does not always cause shell mass reduction in gastropods (Marshall et al., 2008; Lardies et al., 2014; Chen et al., 2015). Shell growth depends on both carbonate saturation of the surrounding water and feeding opportunities (in turn affecting energetic status), whereas dissolution relates solely to the external saturation state. We recorded shell-shortening and more globular-shaped shells in acidified-site populations of $P$. sulcatus (Fig. 5). In these snails there was apical and upperspire erosion as well broadening of the shell aperture. Basal broadening likely relates to slower growth in the acidified areas.

Gastropod shell surface erosion was a sensitive marker of acidification by recording shell loss that was not readily detectable gravimetrically. This finding extends the known benefits of this biomarker of seawater acidity from oceanic and estuarine gastropods (Marshall et al., 2008; Bednaršek et al., 2012a, 2012b, 2014) to rocky shore animals and ecosystems. Our manuallyassessed eroded surface area for $N$. chamaeleon correlated with that computed digitally, although the latter was more accurate as it accounted for small eroded areas between shell ribs. Shell erosion ranking sharply distinguished acidified and reference sites. Median scores for $N$. chamaeleon from references sites were half the value of those for acidified sites (Fig. 8), and similar clear distinction was found for P. sulcatus (Fig. 9). Frequency distributions show that that the highest erosion ranks only occur in the low pH sites (Figs 8 and 9). The few cases of low erosion ranks at the acidified sites may represent within-shore movement, whereby snails initially inhabiting higher $\mathrm{pH}$ water lower on the shore had recently moved into the more acidified higher-shore habitats.

Whereas the number of ranks and the value ascribed to each rank are arbitrary, variation in rank frequency across habitats is important. Despite using different approaches to rank shell erosion, both species showed high frequencies of unique highest (or higher) ranks in acidifed site populations (>0.4), suggesting similarity in their acidification biomonitoring potential. 
Our system can however be tailored to the scope and precision needs of an investigation. For instance, it is possible to get three-dimensional information about erosion, by integrating dissolution areas with shell thickness measurements (Figs 2 and 3). Although we focused on measuring and ranking the areas of eroded shell surfaces, shell erosion could be estimated from a spiral growth line superimposed on apically-viewed shell images (A6). Erosion could be measured in terms of the ratio of the line length between the growing edge and the eroded shell against the entire growth line (A6). Improvements could also involve integrating shell growth rate and mineralogy of the study species with shell erosion measures.

\section{Appraisal of the biomonitoring tool}

Gastropod shell erosion as a biomonitoring tool has advantages over buoys fitted with loggers. We were able to use benthic gastropods in intertidal habitats and because they are usually slow moving or sedentary (occupying meter-sized areas), they can be used to monitor acidification over a range of spatial scales, from metres to hundreds of kilometres. Sampling across a region allows identification of areas with greater or lesser impacts of acidification. In addition to recording chronic exposure of individuals, this approach to biomonitoring can compare populations over time (see A7). Assessments of shell erosion are cost-effective and simple to execute without requiring meters or instruments, such that this could gain the involvement and benefits of citizen science (Dickinson et al., 2010; Gaston et al., 2018). Moreover, information on acidification experienced by individual organisms using shell erosion ranking can be related to other parameters (mass, age, growth and reproduction) of the same organism in the field.

There are important considerations when using shell erosion as a biomarker of seawater acidification. Because time is a function of acidified seawater exposure, similar-aged individuals (such as adults) should be used in biomonitoring exercises. Distinguishing shell dissolution from weathering and bioerosion is not trivial (Schönberg et al., 2017). Shells become worn through daily cycles of heating, cooling, wetting and drying which increase with increasing vertical shore height (Underwood, 1979; Denny, 1988). Shell abrasion also increases with more wave action and/or exposure to suspended sediments (Denny, 1988). It is possible to tell the effects of bioerosion and erosion by acidified water apart, with the characteristic pits and burrows of microborers often becoming conspicuous on shells. Weathering, bioerosion and chemical erosion work together in acidified waters and are accelerated if outer protective layers of the shell are lost. This problem can be surpassed by establishing reference sites that show what shells are like in normal conditions as compared to 
acidified conditions. In any event, gross shell erosion (as indicated by maximum SER values, Figs 8 and 9), shell deformities and corroded shells in juveniles are independently clear signs of acidified water exposure (Hall-Spencer et al., 2008; Marshall et al., 2008, 2016; Harvey et al., 2018). Notably, gross shell erosion follows exposure to undersaturated carbonate conditions irrespective of the processes driving these, thus this biomarker informs about a change in environmental conditions and not the underlying mechanism.

Information on the ecology and biology of biomonitor species is crucial (Phillips and Rainbow, 1995). Species attributes such as shell size and thickness, mineralogy, growth rate, animal behaviour and distribution are all important considerations. Biomonitoring potential is likely to vary between gastropod species considering that mineralogy intrinsically influences natural weathering. Local abundance and geographical distribution of a species add value to its use as a biomonitor. Our study species are common rocky intertidal inhabitants and can potentially be used to monitor acidificaiton across the vast Central Indo-Pacific ecoregion (Spalding et al. 2007; Palomares and Pauly, 2019). The methods we propose nonetheless provide a framework for developing acidification biomonitoring using other gastropod species across a wide spectrum of marine environments.

\section{Conclusions}

We show that gastropod shells can be used to assess the presence and effects of acidification in nearshore and benthic coastal marine environments. This has advantages over conventional monitoring in heterogeneous intertidal systems and allows the identification of criticallyexposed areas. In addition to indicating acidic discharges into coastal ecosystems, such biomonitoring could help assess the extent of anthropogenic ocean acidification. Though some refinement and standardization of protocols is required, gastropods show potential for biomonitoring of acidification in marine ecosystems.

\section{Acknowledgments}

DJM is funded through the grant UBD/RSCH/1.4/FICBF(b)/2018/016. SG is the recipient of a research grant UBD/CRG\#18. JH-S is funded by the International Educational and Research Laboratory Program of the University of Tsukuba. Azmi Aminuddin, Amalina Brahim and David Relex helped collect and photograph snails.

\section{Author contributions}


DJM conceived the original idea and JH-S further contextualized this; DJM and DTTW devised methods and approaches; DJM and NM collected, photographed and measured snails; LCDS developed the automated segmentation technique; SG provided input on the geology of the area as well as the supplementary figures. AAA undertook geometric morphometric analysis. All authors contributed to preparing and critically commenting on the manuscript.

9. Conflicts of Interest: The authors declare no conflicts of interest

\section{References}

Abdelhady, A.A., 2016. Phenotypic differentiation of the Red Sea gastropods in response to the environmental deterioration: geometric morphometric approach. J. Afr. Earth Sci. 115, $191-202$.

Abdelhady, A.A., Abdelrahman, E., Elewa, A.M.T., Fan, J., Zhang, S., Xiao, J., 2018. Phenotypic plasticity of the gastropod Melanoides tuberculata in the Nile Delta: A pollutioninduced stabilizing selection. Mar. Pollut. Bull. 133, 701-710. https://doi.org/10.1016/j.marpolbul.2018.06.026

Abdelhady, A.A., Fürsich, F.T., 2014. Macroinvertebrate palaeo-communities from the Jurassic succession of Gebel Maghara (Sinai, Egypt). J. African Earth Sci. 97, 173-193. https://doi.org/10.1016/j.jafrearsci.2014.04.019

Abdelhady, A.A., Fürsich, F.T., 2015. Sequence architecture of a Jurassic ramp succession from Gebel Maghara (North Sinai, Egypt): Implications for eustasy. J. Palaeogeogr. 4, 305330. https://doi.org/10.1016/j.jop.2015.08.008

Azhar, A.S., Latiff, A.H.A., Lim, L.H., Gödeke, S.H., 2019. Groundwater investigation of a coastal aquifer in Brunei Darussalam using seismic refraction. Environ. Earth Sci. 78, 220. https://doi.org/10.1007/s12665-019-8203-6

Bednaršek, N., Feely, R.A., Reum, J.C.P., Peterson, B., Menkel, J., Alin, S.R., Hales, B., 2014. Limacina helicina shell dissolution as an indicator of declining habitat suitability owing to ocean acidification in the California Current Ecosystem. Proc. R. Soc. B Biol. Sci. 281, 20140123-20140123. https://doi.org/10.1098/rspb.2014.0123 
377 Bednaršek, N., Tarling, G.A., Bakker, D.C.E., Fielding, S., Cohen, A., Kuzirian, A., McCorkle, D., Lézé, B., Montagna, R., 2012b. Description and quantification of pteropod shell dissolution: a sensitive bioindicator of ocean acidification. Glob. Chang. Biol. 18, 2378-2388. https://doi.org/10.1111/j.1365-2486.2012.02668.x

Bednaršek, N., Tarling, G.A., Bakker, D.C.E., Fielding, S., Jones, E.M., Venables, H.J., Ward, P., Kuzirian, A., Lézé, B., Feely, R.A., Murphy, E.J., 2012a. Extensive dissolution of live pteropods in the Southern Ocean. Nat. Geosci. 5, 881-885. https://doi.org/10.1038/ngeo1635

Begliomini, F.N., Maciel, D.C., de Almeida, S.M., Abessa, D.M., Maranho, L.A., Pereira, C.S., 387 Yogui, G.T., Zanardi-Lamardo, E., Castro, Í.B., 2017. Shell alterations in limpets as putative biomarkers for multi-impacted coastal areas. Environ. Pollut. 226, 494-503. https://doi.org/10.1016/j.envpol.2017.04.045

Bolhuis, H., Schluepmann, H., Kristalijn, J., Sulaiman, Z., Marshall, D.J., 2014. Molecular analysis of bacterial diversity in mudflats along the salinity gradient of an acidified tropical Bornean estuary (South East Asia). Aquat. Biosyst. 10, 1-13. https://doi.org/10.1186/20469063-10-10

Cai, W.-J., 2011a. Estuarine and coastal ocean carbon paradox: $\mathrm{CO}_{2}$ sinks or sites of terrestrial 398 carbon incineration? Ann. Rev. Mar. Sci. 3, 123-145. https://doi.org/10.1146/annurev-marine$\underline{120709-142723}$

Cai, W.-J., Hu, X., Huang, W.-J., Murrell, M.C., Lehrter, J.C., Lohrenz, S.E., Chou, W.-C., 401 Zhai, W., Hollibaugh, J.T., Wang, Y., Zhao, P., Guo, X., Gundersen, K., Dai, M., Gong, G.C., 2011b. Acidification of subsurface coastal waters enhanced by eutrophication. Nat. Geosci. 4, 766-770. https://doi.org/10.1038/ngeo1297

404

Chen, Y.J., Wu, J.Y., Chen, C.T.A., Liu, L.L., 2015. Effects of low-pH stress on shell traits of 406 the dove snail, Anachis misera, inhabiting shallow-vent environments off Kueishan Islet, 407 Taiwan. Biogeosci. 12, 2631-2639. https://doi.org/10.5194/bg-12-2631-2015 
409 Connell, S.D., Doubleday, Z.A., Hamlyn, S.B., Foster, N.R., Harley, C.D.G., Helmuth, B., 410 Kelaher, B.P., Nagelkerken, I., Sarà, G., Russell, B.D., 2017. How ocean acidification can benefit calcifiers. Curr. Biol. 27, R95-R96. https://doi.org/10.1016/j.cub.2016.12.004

Denny, M., 1988. Biology and the mechanics of the wave swept environment. Princeton 414 University Press, New Jersey.

Dickinson, J.L, Zuckerberg, B., Bonter, D.N., 2010. Citizen science as an ecological research tool: challenges and benefits. Annu. Rev. Ecol. Syst. 41, 49-172, https://doi.org/10.1146/annurev-ecolsys-102209-144636

Doubleday, Z.A., Nagelkerken, I., Connell, S.D., 2017. Ocean life breaking rules by building shells in acidic extremes. Curr. Biol. 27, R1104-R1106. https://doi.org/10.1016/j.cub.2017.08.057

Duarte, C.M., Hendriks, I.E., Moore, T.S., Olsen, Y.S., Steckbauer, A., Ramajo, L., Carstensen, J., Trotter, J.A., McCulloch, M., 2013. Is ocean acidification an open-ocean syndrome? Understanding anthropogenic impacts on seawater pH. Estuaries and Coasts 36, 221-236. https://doi.org/10.1007/s12237-013-9594-3

Duquette, A., McClintock, J.B., Amsler, C.D., Pérez-Huerta, A., Milazzo, M., Hall-Spencer, J.M., 2017. Effects of ocean acidification on the shells of four Mediterranean gastropod species near a $\mathrm{CO}_{2}$ seep. Mar. Pollut. Bull. 124, 917-928. https://doi.org/10.1016/j.marpolbul.2017.08.007 Foggo, A., Twitchett, R.J., Hall-Spencer, J.M., Milazzo, M., 2015. Physiological advantages of dwarfing in surviving extinctions in high- $\mathrm{CO}_{2}$ oceans. Nat. Clim. Chang. 5, 678-682. https://doi.org/10.1038/nclimate2616 ecology. TREE, 33, 916-925. 
Gibbs, P.E., Bryan, G.W., Pascoe, P.L., Burt, G.R., 1987. The use of the dog-whelk, Nucella lapillus, as an indicator of tributyltin (TBT) contamination. J. Mar. Biol. Assoc. United Kingdom 67, 507-523. https://doi.org/10.1017/S0025315400027260

Grealish, G.J., Fitzpatrick, R.W., 2013. Acid sulphate soil characterization in Negara Brunei Darussalam: a case study to inform management decisions. Soil Use Manag. 29, 432-444. https://doi.org/10.1111/sum.12051

Hall-Spencer, J.M., Rodolfo-Metalpa, R., Martin, S., Ransome, E., Fine, M., Turner, S.M., Rowley, S.J., Tedesco, D., Buia, M-C. 2008. Volcanic carbon dioxide vents show ecosystem effects of ocean acidification. doi:10.1038/nature07051

453

Hammer, Ø., Harper, D.A.T., Ryan, P.D., 2001. PAST: paleontological statistics software package for education and data analysis. Palaeontol. Electronica 4, 1-9.

Harvey, B.P., Agostini, S., Wada, S., Inaba, K., Hall-Spencer, J.M., 2018. Dissolution: the 458 Achilles' heel of the Triton shell in an acidifying ocean. Front. Mar. Sci. 5, 1-11. https://doi.org/10.3389/fmars.2018.00371

460

Harvey, B.P., McKeown, N.J., Rastrick, S.P.S., Bertolini, C., Foggo, A., Graham, H., HallSpencer, J.M., Milazzo, M., Shaw, P.W., Small, D.P., Moore, P.J., 2016. Individual and population-level responses to ocean acidification. Sci. Rep. 6, 20194. https://doi.org/10.1038/srep20194

Hossain, M.B., Marshall, D.J., 2014. Benthic infaunal community structuring in an acidified tropical estuarine system. Aquat. Biosyst. 10, 11. https://doi.org/10.1186/2046-9063-10-11

Hossain, M.B., Marshall, D.J., Venkatramanan, S., 2014. Sediment granulometry and organic matter content in the intertidal zone of the Sungai Brunei estuarine system, northwest coast of Borneo. Carpathian J. Earth Environ. Sci. 9, 231-239. 
475 Concholepas concholepas populations. J. Sea Res. 90, 127-134.

476 https://doi.org/10.1016/j.seares.2014.03.010

477

Majewska, R., Adam, A., Mohammad-Noor, N., Convey, P., De Stefano, M., Marshall, D.J., 2017. Spatio-temporal variation in phytoplankton communities along a salinity and $\mathrm{pH}$ gradient in a tropical estuary (Brunei, Borneo, South East Asia). Trop. Ecol. 58, 251-269.

Marshall, D.J., Aminuddin, A., Ahmad, S., 2018. Gastropod diversity at Pulau Punyit and the nearby shoreline - a reflection of Brunei's vulnerable rocky intertidal communities. Sci. Bruneiana 17, 34-40.

485

Marshall, D.J., Proum, S., Hossain, M.B., Adam, A., Hoon Lim, L., Santos, J.H., 2016.

Ecological responses to fluctuating and extreme marine acidification: lessons from a tropical estuary (the Brunei Estuarine System). Sci. Bruneiana Special Is, 1-12.

Marshall, D.J., Santos, J.H., Leung, K.M.Y., Chak, W.H., 2008. Correlations between Res. 66, 422-429. https://doi.org/10.1016/j.marenvres.2008.07.003

493

Márquez, F., Nieto Vilela, R.A., Lozada, M., Bigatti, G., 2015. Morphological and behavioral differences in the gastropod Trophon geversianus associated to distinct environmental conditions, as revealed by a multidisciplinary approach. J. Sea Res. 95, 239-247. https://doi.org/10.1016/j.seares.2014.05.002

498

Morley, C.K., Back, S., Van Rensbergen, P., Crevello, P., Lambiase, J.J., 2003. Characteristics of repeated, detached, Miocene-Pliocene tectonic inversion events, in a large delta province on an active margin, Brunei Darussalam, Borneo. J. Struct. Geol. 25, 1147-1169. https://doi.org/10.1016/S0191-8141(02)00130-X

Nuñez, J.D., Laitano, M. V., Cledón, M., 2012. An intertidal limpet species as a bioindicator: 
508

509

510

511

512

513

514

515

516

517

518

519

520

521

522

523

524

525

526

527

528

529

530

531

532

533

534

535

536

537

538

539

Palomares, M.L.D. and D. Pauly. Editors. 2019. SeaLifeBase. World Wide Web electronic publication. www.sealifebase.org, version (04/2019)

Phillips, D.J.H., Rainbow, P.S., 1993. Biomonitoring of trace aquatic contaminants. Springer Netherlands, Dordrecht, pp. 133-178. https://doi.org/10.1007/978-94-011-2122-4_6

Powell, B., Martens, M., 2005. A review of acid sulfate soil impacts, actions and policies that impact on water quality in Great Barrier Reef catchments, including a case study on remediation at East Trinity. Mar. Pollut. Bull. 51, 149-164. https://doi.org/10.1016/j.marpolbul.2004.10.047

Proum, S., Harley, C.D., Steele, M., Marshall, D.J., 2017. Aerobic and behavioral flexibility allow estuarine gastropods to flourish in rapidly changing and extreme $\mathrm{pH}$ conditions. Mar. Biol. 164, 97. https://doi.org/10.1007/s00227-017-3124-y

Proum, S., Santos, J.H., Lim, L.H., Marshall, D.J., 2016. Metal accumulation in the tissues and shells of Indothais gradata snails inhabiting soft and hard substrata in an acidified tropical estuary (Brunei, South East Asia). Reg. Stud. Mar. Sci. 8, 487-497. https://doi.org/10.1016/j.rsma.2016.03.010

Proum, S., Santos, J.H., Lim, L.H., Marshall, D.J., 2018. Tidal and seasonal variation in carbonate chemistry, $\mathrm{pH}$ and salinity for a mineral-acidified tropical estuarine system. Reg. Stud. Mar. Sci. 17, 17-27. https://doi.org/10.1016/j.rsma.2017.11.004

Rohlf, F.J., 1996. Morphometric spaces, shape components and the effects of linear transformations, in: Marcus, L.F., Corti, M., Loy, A., Naylor, G.J.P., Slice, D.E. (Eds.), Advances in Morphometrics. Springer US, Boston, MA, pp. 117-129. https://doi.org/10.1007/978-1-4757-9083-2_11

Rohlf, F.J., Slice, D., 1990. Extensions of the Procrustes method for the optimal superimposition of landmarks. Syst. Biol. 39, 40-59. https://doi.org/10.2307/2992207 
540 Schönberg, C.H.L., Fang, J.K.H., Carreiro-Silva, M., Tribollet, A., Wisshak, M., 2017.

541 Bioerosion: the other ocean acidification problem. ICES J. Mar. Sci. 74, 895-925.

542 https://doi.org/10.1093/icesjms/fsw254

543

544 Spalding, M.D., Fox, H.E., Allen, G.R., Davidson, N., Ferdaña, Z.A., Finlayson, M., Halpern,

545 B.S., Jorge, M.A., Lombana, A., Lourie, S.A., Martin, K.D., Mcmanus, E., Molnar, J., Recchia,

546 C.A., Robertson, J., 2007. Marine ecoregions of the world: A bioregionalization of coastal and

547 shelf areas. Bioscience, 57, 573-583.

548

549

Underwood, A.J., 1979. The ecology of intertidal gastropods. Adv. Mar. Biol. 16, 111-210.

550

https://doi.org/10.1016/S0065-2881(08)60293-x

551

552 Urish, D.W., McKenna, T.E., 2004. Tidal effects on ground water discharge through a sandy

553 marine beach. Ground Water 42, 971-982. https://doi.org/10.1111/j.1745-

Waska, H., Greskowiak, J., Ahrens, J., Beck, M., Ahmerkamp, S., Böning, P., Brumsack, H.J., Degenhardt, J., Ehlert, C., Engelen, B., Grünenbaum, N., Holtappels ,M., Pahnke, K., Marchant, H.K., Massmann, G., Meier, D., Schnetger B., Schwalfenberg, K., Simon, H., Vandieken, V., Zielinski, O., Dittmar, T. 2019. Spatial and temporal patterns of pore water chemistry in the inter-tidal zone of a high energy beach. Front. Marine. Sci. https://doi.org/10.3389/fmars.2019.00154

Zelditch, M.L, Swiderski, D.L., Sheets, H.D., 2012. Geometric morphometrics for biologists: A primer. Elsevier Academic Press, London.

Zhai, W.-D., Zang, K.-P., Huo, C., Zheng, N., Xu, X.-M., 2015. Occurrence of aragonite corrosive water in the North Yellow Sea, near the Yalu River estuary, during a summer flood. Estuar. Coast. Shelf Sci. 166, 199-208. https://doi.org/10.1016/j.ecss.2015.02.010 https://doi.org/10.1016/j.aca.2007.11.018 
Figure captions

Figure 1. Physical map showing sampling sites and waterways in Brunei Darussalam (Borneo, South East Asia). JPMC (Jerudong Park Medical Centre), 456'55', N, 11449'42' 'E; PJER

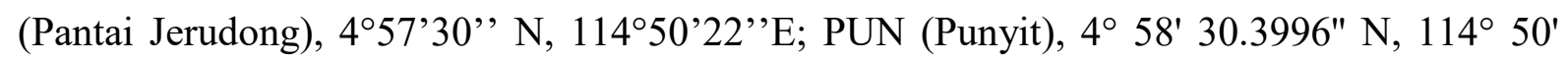
56.7996"E; E1 (Empire), 458’08', N, 11451'18'’E; E2 (Empire), 458'05', N, 11451'20' 'E; E3 (Empire), 458'05' N, 11451'19' 'E; TP (Pantai Tungku), 458'13'” N,

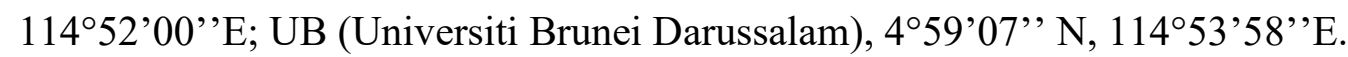

589

Figure 2. Shell erosion ranking in Nerita chamaeleon (apical view). A quadrant and seven sectors based on the shell growth pattern were established from a line drawn between the columella notch (b) and the apex (circled a). The apex is the oldest shell with the growing edge (labelled c) in sector 7. Two depths (types) of erosion were scored, Type I is deep erosion to the fine textured, grey/white layer and Type II is superficial erosion of the pigmented, ridged layer under the periostracum. A score was based on the highest sector showing $>50 \%$ eroded shell. Shell A shows no erosion with the periostracum intact to the apex, shell B shows a ruffled periostracum covering $>50 \%$ of sector 6 (scores 5 for Type II) and shell C shows complete Type I erosion in sector 5 and complete Type II erosion in sector 7.

598 Figure 3. Shell erosion ranking in Planaxis sulcatus (abapertural view). R1 (not shown), shell 599 whorls 1 and 2 (W1, W2) intact with fine ridges; R2, complete or incomplete ridges on W3; 600 R3, W3 completely worn but W4 mostly ridged; R4, W4 mostly to completely worn but body 601 whorl (WB) completely ridged; R5, WB eroded towards the right edge. 
602

603

604

605

606

607

608

609

610

611

612

613

614

615

616

617

618

619

620

621

622

623

624

625

626

627

628

629

630

631

Figure 4. Upper and middle. $\mathrm{pH}$ and salinity at acidified sites E1, E2 and E3 and reference sites, JMPC, PJER and PUN ( $\mathrm{n}=103)$. TP and UB were similar to other reference sites ( $\mathrm{pH}$ was $8.44-8.29$ and salinity was $33.1-31 \mathrm{psu} ; \mathrm{n}=21$ ). Bottom. Relationship between $\mathrm{pH}$ and salinity at the acidified sites, with boxes showing conditions likely to cause calcite (Ca) or aragonite (Ar) undersaturation (see Proum et al., 2018).

Figure 5. 2D-DCA plot (axes 1 vs. axis 2) for P. sulcatus shells from an acidified site (E2, blue squares) and reference sites (UB, red crosses and TP, green crosses). TPS deformation grids represent individuals located at both extremes of the $\mathrm{x}$ and $\mathrm{y}$ axes. The population from the acidified site (E2, blue squares) overlaps weakly with reference populations. Correlations show that DC1 is especially influenced by aperture shape and DC2 by shell height. ANOSIM results were $\mathrm{UB} / \mathrm{E} 2, \mathrm{p}=0.01 ; \mathrm{UB} / \mathrm{TP}, \mathrm{p}=0.0177 ; \mathrm{E} 2 / \mathrm{TP}, \mathrm{p}=0.0001$.

Figure 6. Eroded and total abapertural surface areas of $N$. chamaeleon shells from PUN (reference, blue, $\mathrm{n}=25$ ) and $\mathrm{E} 1$ (acidified, red, $\mathrm{n}=15$ ), determined manually (A, B, C; mean \pm 1 s.e.m). (D) Number of individuals with eroded (> 10\%) and non-eroded shells.

Figure 7. Examples showing red-blue-white colour partitioning of shell surfaces, used in the automated determination of percentage shell erosion (upper). Pixel numbers and percentage erosion calculations are shown. A least squares linear regression relating manually and digitally determined percentage erosion (lower).

Figure 8. Nerita chamaeleon shell erosion ranks (SER). (A) Box-Whisker plots and outliers of SERs for three acidified (E1, E2, E2) and three reference (JPMC, PJER, PUN) sites using combined Type I and II ranks (0-14). Different letters above plots indicate significant differences between sites (see Table 1). (B) Snail frequencies at each site for Type I rank (0$6)$.

Figure 9. Planaxis sulcatus shell erosion ranks (SER). (A) Box-Whisker plots and outliers of SERs for three acidified (E1, E2, E2) and three reference (JPMC, PJER, PUN) sites for apertural and abapertural surface ranks combined (2-10). Different letters above plots indicate significant differences between sites (see Table 1). (B) Snail frequencies at each site (ranks 25). 